\title{
Open Heart Surgery in Haseki Training and Research Hospital: Evaluation of the First 500 Cases
}

\section{Haseki Eğitim ve Araştırma Hastanesi'nde Açık Kalp Cerrahisi: Illk 500 Olgunun Değerlendirilmesi}

\author{
๑ Mazlum Şahin, ๑ Cihan Yücel, ๑ Fatma Tuğba Illal Mert, ๑ Semi Öztürk* \\ University of Health Sciences, Haseki Training and Research Hospital, Clinic of Cardiovascular Surgery, İstanbul, Turkey \\ *University of Health Sciences, Haseki Training and Research Hospital, Clinic of Cardiology, Istanbul, Turkey
}

\section{Abstract}

Aim: The purpose of this study was to evaluate outcomes of the first 500 open heart surgeries performed in the Department of Cardiovascular Surgery at Haseki Training and Research Hospital, which was founded in 2014.

Methods: Records of 500 open heart surgeries performed between December 2014 and February 2017 were evaluated retrospectively. A total of 374 patients underwent coronary artery bypass grafting, 11 Bentall operation, 41 aortic valve replacement, and thirty eight patients underwent mitral valve replacement (MVR). Tricuspid ring annuloplasty was performed in four patients who had previously undergone MVR and atrial septal defect closure in 12 patients, while five patients were operated due to cardiac myxoma and 20 patients due to type 1 aortic dissection.

Results: The mean age of the patients was 57.6 13.1 years (17-84 years). Hypertension (54.4\%) was the most common comorbidity, followed by hyperlipidemia (43.1\%), diabetes mellitus (34.36\%), Chronic Obstructive Pulmonary disease (21.5\%), and peripheral arterial disease (9.3\%), respectively. In-hospital death occurred in 22 of $480(4.58 \%)$ patients and 10 of 20 patients (50\%) who were operated due to type 1 aortic dissection. The overall hospital mortality rate was $6.4 \%$ (26 of 500 patients).

Conclusion: Our experience showed that world class cardiac care is provided in our center.

Keywords: New center, open heart surgery, coronary artery bypass grafting, valve replacement

\section{Öz}

Amaç: Bu çalışmanın amacı, 2014 yılında faaliyete geçen Haseki Eğitim ve Araştırma Hastanesi Kalp ve Damar Cerrahisi Kliniği'nde yapılan ilk 500 kalp ameliyatının sonuçlarını değerlendirmektir.

Yöntemler: Aralık 2014 - Şubat 2017 tarihleri arasında 500 olgu retrospektif olarak değerlendirildi. Toplam 374 olguda koroner arter bypass cerrahisi uygulandı. On bir hasta Bentall operasyonu, 41 hasta aort kapak replasmanı, 38 hasta mitral kapak replasmanı (MVR), MVR yapılan 4 hasta triküspit ring anuloplasti, 12 hasta atriyal septal defekt kapatıması, 5 hasta kardiyak miksoma, 20 hasta ise tip 1 aort diseksiyonu nedeni ile opere edilmiştir.

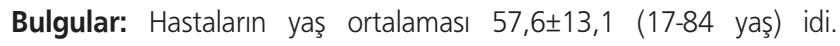
Hipertansiyon $(\% 54,4)$ en sık eşlik eden hastalık olup bunu hiperlipidemi $(\% 43,1)$, diabetes mellitus $(\% 34,36)$, Kronik Obstrüktif Akciğer hastalığı $(\% 21,5)$ ve periferik arter hastalığı $(\% 9,3)$ takip ediyordu. Hastane mortalitesi 480 hastada $22(\% 4,58)$, tip 1 aort diseksiyonu nedeni ile opere edilen 20 hastada ise 10 hasta (\%50) olarak, totalde ise 500 hastada $26(\% 6,4)$ olarak gerçekleşti.

Sonuç: Deneyimlerimiz, merkezimizde dünya çapında kalp bakımı sağlandığını gösterdi.

Anahtar Sözcükler: Yeni merkez, açık kalp cerrahisi, koroner arter bypass greftleme, kapak replasmanı
Address for Correspondence/Yazışma Adresi: Mazlum Şahin

University of Health Sciences, Haseki Training and Research Hospital, Clinic of Cardiovascular Surgery, İstanbul, Turkey

Phone: +90 5346194374 E-mail: mzlmshn@gmail.com ORCID ID: orcid.org/0000-0001-9630-6634 Received/Geliş Tarihi: 11 May 2017 Accepted/Kabul Tarihi: 19 June 2017
${ }^{-}$Copyright 2018 by The Medical Bulletin of University of Health Sciences Haseki Training and Research Hospital
The Medical Bulletin of Haseki published by Galenos Yayınevi.

๑Telif Hakkı 2018 Sağlık Bilimleri Üniversitesi Haseki Eğitim ve Araştırma Hastanesi Haseki Tıp Bülteni, Galenos Yayınevi tarafindan basılmışırı. 


\section{Introduction}

From a historical point of view, for physicians, the heart has always been perceived as a feared organ that especially needs to be kept away from surgery. In the $17^{\text {th }}$ century, nothing could be done to heart injuries. In the $17^{\text {th }}$ century, the belief that "nothing can be done to heart injuries" started to change. Ludwig Reh was the first surgeon to save a patient by stitching myocardium in a heart injury. This operation, performed in 1896, is considered to be the beginning of the heart surgery (1). In the late 19th and early 20th centuries, advances in various branches of medicine -as a natural consequence of scientific and technological developments- played a major role in the rapid development of heart surgery.

The first steps of modern cardiac surgery were taken in Turkey with closed mitral commissurotomy.

In 1953 and 1954, Dr. Nihat Dorken and Dr. Fahri Arel in İstanbul and Dr. Orhan Mumin and Dr. Hilmi Akın in Ankara were the pioneers of this advancement (2). The first open heart surgery, using extracorporeal circulation, was perfomed by Dr. Mehmet Tekdoğan in Hacettepe University Hospital. The first series of open heart surgeries were performed by Dr. Aydın Aytaç in Hacettepe Children's Hospital in 1962 (3).

Currently, there are 75.000 open heart surgeries per year in a total of 260 heart centers, including 42 ministry of health, 52 university and 164 private hospitals (4).

The purpose of this study was to present our experience and results of open heart surgery from the first year of our operation in the Department of Cardiovascular Surgery at Haseki Training and Research Hospital.

\section{Methods}

Records of 500 patients who underwent open heart surgery between December 2014 and February 2017 in Haseki Training and Research Hospital were retrospectively reviewed (Table 1). A total of 374 patients underwent coronary artery bypass grafting (CABG), and among them, six patients had carotid endarterectomy, one left ventricle aneurysm repair, five aortic valve replacement $(A V R)$, three mitral valve replacement (MVR), four mitral ring annuloplasty, and one patient had mitral ring annuloplasty with neochord implantation simultaneously. Out of 374 CABG procedures, 24 cases were performed as off pump, and in three cases, minimal invasive direct $C A B$ (MIDCAB) was preferred. Bentall operation was performed in 11 patients, AVR in 41 patients, MVR in four patients, tricuspid ring annuloplasty in four patients who had previously undergone MVR, and atrial septal defect (ASD) closure in 12 patients were performed, while five patients were operated due to cardiac myxoma and 20 due to type 1 aortic dissection.
In addition to routine preoperative examinations, patients with a history of Chronic Obstructive Pulmonary disease (COPD) or patients with pathological auscultation findings on examination were referred for pulmonology consultation and pulmonary function tests. In CABG preparation, patients with a previous history of cerebrovascular event and peripheral arterial disease and patients over 65 years were examined with bilateral carotid Doppler ultrasonography. Carotid artery angiography was performed in case of significant stenosis in Doppler ultrasonographic evaluation.

Blood sugar levels were closely followed up in diabetic patients and insulin therapy was initiated in patients with high levels after consultation. Patients scheduled for valve surgery were routinely examined by a dental consultant.

Median sternotomy was performed except three MIDCAB cases via left anterior thoracotomy. During cardiopulmonary bypass, mean arterial pressure was maintained at $50-70 \mathrm{mmHg}$.

Myocardial protection was achieved with continuous retrograde blood cardioplegia, whereas antegrade blood cardioplegia was performed at 20 minute intervals. During coronary bypass, proximal anastomoses were performed under side clamp. Antegrade cardioplegia was delivered in only cases with short estimated operation period. Proximal anastomoses were made under cross clamping in the ones with aortic calcifications. Temporary pace

\begin{tabular}{|c|c|c|}
\hline Operation & Number of cases & Percent (\%) \\
\hline CABG & 374 & 74.8 \\
\hline CABG + Carotid endarterectomy & 6 & - \\
\hline CABG + LV Aneurism repair & 1 & - \\
\hline$C A B G+A V R$ & 5 & - \\
\hline$C A B G+M V R$ & 3 & - \\
\hline CABG + Mitral valve repair & 5 & - \\
\hline Off-pump CABG & 24 & - \\
\hline MIDCAB & 3 & - \\
\hline AVR & 41 & 8.2 \\
\hline MVR & 38 & 7.6 \\
\hline $\begin{array}{l}\text { MVR+ tricuspid ring } \\
\text { annuloplasty }\end{array}$ & 4 & - \\
\hline Type 1 aortic dissection & 20 & 4 \\
\hline Ascending aortic aneurism & 11 & 2.2 \\
\hline ASD closure & 10 & 2 \\
\hline Cardiac myxoma & 4 & 0.8 \\
\hline Infectious endocarditis & 2 & 0.4 \\
\hline \multicolumn{3}{|c|}{$\begin{array}{l}\text { CABG: Coronary artery bypass grafting, AVR: Aortic valve replacement, MVR: } \\
\text { Mitral valve replacement, LV: Left ventricle, MIDCAB: Minimal invasive direct } \\
\text { coronary artery bypass, ASD: Atrial septal defect }\end{array}$} \\
\hline
\end{tabular}


maker was fitted in coronary bypass and valve patients suffering from arrhythmia. In patients who had uneventful intensive care unit stay, thoracic drains and Foley catheters were removed on the second postoperative day and the patients were taken to the follow-up clinic.

\section{Statistical Analysis}

No statistical tests were used. Data was expressed as mean \pm standard deviation.

\section{Results}

Three hundred ten cases were male (62\%) and 190 were female $(38 \%)$ and the mean age was $57.6 \pm 13.1$ (31-84) years. According to the preoperative data of the patients, hypertension (44.4\%) was the most common comorbid disease, followed by hyperlipidemia (35.2\%), diabetes mellitus (31\%), and COPD (17.6\%). Twenty patients had preoperative renal dysfunction and one patient required chronic dialysis. Thirty eight patients had accompanying peripheral artery disease while 14 patients had a cerebrovascular event (Table 2).

According to the European System for Cardiac Operative Risk Evaluation (euroSCORE) risk scoring system, 170 patients were in the low-risk group (0-2 points), 235 in the medium-risk group (3-5 points) and 95 in the highrisk group (six and above).

The mean aortic cross clamp time and cardiopulmonary bypass time (CPB) were calculated as $64.3 \pm 25.9$ minutes and 103.2 \pm 45.6 minutes, respectively. The longest pump time was 380 minutes in Bentall procedure+hemiarch replacement for type 1 aortic dissection. The shortest pump duration was 20 minutes with an ASD operation. Average drainage amount was $458.2 \pm 303.2 \mathrm{~mL}$. The mean duration of intensive care unit stay was $34.7 \pm 15.0$ hours and the mean length of hospital stay was $7.3 \pm 4.8$ days.

\begin{tabular}{|c|c|c|}
\hline & Number of patients & Percent (\%) \\
\hline \multicolumn{3}{|l|}{ Sex } \\
\hline Female & 190 & 38 \\
\hline Male & 310 & 62 \\
\hline Hypertension & 222 & 44.4 \\
\hline Hyperlipidemia & 176 & 35.2 \\
\hline DM & 155 & 31 \\
\hline COPD & 88 & 17.6 \\
\hline Peripheral Arterial disease & 38 & 7.6 \\
\hline CKD & 20 & 4 \\
\hline CVE & 14 & 2.8 \\
\hline \multicolumn{3}{|c|}{$\begin{array}{l}\text { DM: Diabetes mellitus, COPD: Chronic Obstructive Pulmonary disease, CKD: } \\
\text { Chronic kidney disease, CVE: Cerebrovascular events }\end{array}$} \\
\hline
\end{tabular}

Preoperative ejection fraction (EF), calculated with echocardiography, was $53.12 \%( \pm 25.8)$. The lowest EF was $25 \%$. EF in 20 patients was below $35 \%$. EF in 160 patients was between $30 \%$ and $50 \%$. Five of the 26 deceased patients were over 70 years of age, and EF in six patients was less than $30 \%$. The total perfusion and cross clamp times were longer than the mean total perfusion and cross clamp times in the lost patients.

Of the 500 patients who underwent open heart surgery, 32 died. The mortality rate was $6.4 \%$. Ten deaths were due to emergent operation for type 1 aortic dissection; 14 had coronary bypass, one had AVR and one had MVR+CABG. Resuscitative sternotomy was performed in five cases of type 1 aortic dissection. Two of five cases died during procedure. Three of these five patients could not be weaned from CPB pump. The other two patients used extracorporeal membrane oxygenator. Three patients died due to cardiac failure whereas four patients died due to sepsis. Five of the 26 deaths were in patients over 70 years of age. According to euroSCORE II, 15 patients were belonged to high-risk; eight patients to moderate-risk, and three patients belonged to low-risk groups. Five patients failed to be weaned from the pump and died (three patients had aortic dissection and two patients had (ABG). Intra-aortic balloon pump was inserted in three patients before operation, in eight patients during operation, and in seven patients during intensive care follow-up.

The number of revascularized vessels was $2.7 \pm 1.1$ (1-5). Of 374 cases with $C A B G$, full arterial revascularization was performed in four cases, and bilateral internal mammary artery (IMA) was used in 18 cases. In nine procedures, left IMA (LIMA) was not used due to dissection. Off-pump bypass was performed in 24 patients who had low EF and high risk factors for $C P B$, such as history of cancer. The mean number of bypasses in off-pump bypass patients was 1.1 $\pm 1(1-3)$.

Transesophageal echocardiography (TEE) was performed in patients who were scheduled for valve operations. Repair of mitral and tricuspid valve was performed in appropriate cases. Concomitant mitral ring annuloplasty was performed in four patients who underwent $C A B G$, mitral ring annuloplasty and neocordal transfer in one patient, and tricuspid ring annuloplasty was performed in four patients who underwent MVR. All the patients who underwent valve repair were evaluated with preoperative TEE. None of the patients had more than mild levels of valve insufficiency in postoperative evaluation.

In 20 type 1 aortic dissection operations, one ascending aortic graft interposition, six Bentall operation and 13 Bentall+hemiarc replacement were performed. Femoral artery was cannulated in three cases which was performed 
under open chest cardiopulmonary resuscitation while axillary artery was used in other cases. Total circulatory arrest (TCA) and anterograde cerebral perfusion was used routinely. The mean TCA duration was 13.5 ( \pm 5.8$)$ min.

Primary repair was performed in two patients and pericardial patch was used in eight patients who underwent ASD repair.

The most frequent complication in 112 patients (22.4\%) was atrial fibrillation (AF). Direct current cardioversion was performed in patients in whom initial medical cardioversion failed to restore sinus rhythm. Chronic AF was present in three patients. Low cardiac output syndrome and wound infections were other common complications. Mediastinitis developed in two patients (0.4\%) (Table 3).

\begin{tabular}{|c|c|c|c|}
\hline \multicolumn{2}{|l|}{ Mortality } & \multirow{2}{*}{$\begin{array}{l}\text { Number } \\
32\end{array}$} & \multirow{2}{*}{$\begin{array}{l}\text { Percent } \\
\text { (\%) }\end{array}$} \\
\hline Total & 500 & & \\
\hline & 480 & 22 & 4.58 \\
\hline $\begin{array}{l}\text { Aortic } \\
\text { dissection }\end{array}$ & 20 & 10 & 50 \\
\hline \multirow[t]{12}{*}{ Morbidity } & Atrial fibrillation & 112 & 22.4 \\
\hline & Superficial wound infection & 14 & 2.8 \\
\hline & Mediastinitis & 2 & 0.4 \\
\hline & Low cardiac output syndrome & 30 & 6 \\
\hline & Intra-aortic balloon pump & 28 & 5.6 \\
\hline & Respiratory failure & 11 & 2.2 \\
\hline & Hemiparesis & 6 & 1.2 \\
\hline & Hemiplegia & 2 & 0.4 \\
\hline & Revision due to bleeding & 14 & 2.8 \\
\hline & $\begin{array}{l}\text { Revision due to sternum } \\
\text { dehiscence }\end{array}$ & 4 & 0.8 \\
\hline & Myocardial infarction & 5 & 1 \\
\hline & Chronic atrial fibrillation & 3 & 0.6 \\
\hline $\begin{array}{l}\text { MICUS } \\
\text { (days) }\end{array}$ & - & $34.7 \pm 15.0$ & - \\
\hline MHS (days) & - & $7.3 \pm 4.8$ & - \\
\hline
\end{tabular}

\section{Discussion}

In a crowded metropolis like İstanbul, each day a new heart center is being established. However, the most important pitfall in a new heart center is the efficacy. Taking into consideration the fact that the efficacy rate is less than $20 \%$ in $1 / 3$ of the heart surgery centers in our country (5), reaching an open heart count of 500 in the first two years of a new clinic confirmed effective planning beyond the success. Since public hospitals provide health care to all citizens without social security distinction, open heart surgery makes these hospitals more advantageous for patients. It has been reported that mortality rate in combined surgeries and emergency surgeries are higher than in isolated and elective surgeries (6). In our clinic, the mortality rate in patients who underwent elective, emergency and combined surgeries significantly differed. It is known that mortality increases in patients with impaired left ventricular systolic function. Compared with younger patients, cardiac surgery in older patients is associated with higher mortality and morbidity $(7,8)$. There was no correlation between age and mortality in our study, but low EF was significant. As stated in the literature, expected mortality rates in low-risk, middle-risk and highrisk patients are $1.11 \pm 0.07 \%, 5.18 \pm 2.08 \%, 8.78 \pm 3.54 \%$, respectively (9). Our mortality rates were $0.5 \%$ in the lowrisk group, $4.1 \%$ in the middle-risk group, $8.2 \%$ in the highrisk group and $5.2 \%$ in the total risk group. The incidence of postoperative new AF varies between 15\% and $40 \%$ after cardiac surgery (10). AF occurred in 112 cases (22.4\%) and three patients were discharged with AF. Although mediastinitis is a rare complication (1\%-3\%) of open heart surgery, it is one of the most lethal complications and the mortality rate is $10 \%-25 \%$ (11). Mediastinitis developed in two patients.

CABG is at the forefront in our clinic as it is in most centers. Today, there are many alternative surgical methods for $C A B G$. Considering the long-term survival of the patient, we essentially selected LIMA for the graft of choice and preferred bilateral IMA when convenient. Appropriate patients were definitely operated under CPB whereas off-pump surgery was preferred for patients with high risk for $\mathrm{CPB}$.

Our clinic has 10 inpatient beds, four intensive care beds and two operating rooms. With existing conditions, 500 open heart surgeries were performed with acceptable mortality and morbidity during this period since foundation. Our goal is not only to increase the number of operations, but also to increase the diversity of operations and to apply new surgical methods to appropriate patients in the light of new developments.

\section{Study Limitations}

This study has limitations. It is a retrospective study, with the typical limitations inherent in this study design. Besides, the number of patients was small. Although a small sample size was planned, as this was merely a pilot study, large randomized controlled trials should be performed in the future to confirm our results.

\section{Conclusion}

Our experience showed that world class cardiac care is provided in our center. High efficacy in cardiovascular 
surgery can be maintained in a new clinic in an accurately organized hospital.

\section{Ethics}

Ethics Committee Approval: Retrospective study.

Informed Consent: It was taken.

Peer-review: Externally peer-reviewed.

\section{Authorship Contributions}

Surgical and Medical Practices: M.Ş. Concept: M.Ş. Design: S.Ö. Data Collection or Processing: C.Y., M.Ş. Analysis or Interpretation: F.T.i.M. Literature Search: M.Ş., S.Ö. Writing: M.Ş.

Conflict of Interest: No conflict of interest was declared by the authors.

Financial Disclosure: The authors declared that this study received no financial support.

\section{References}

1. Aylin Ö, Öztekin O. Dünden Bugüne Kalp Cerrahisi. Turk Gogus Kalp Dama Cer Derg 1999;3:153-60.

2. Tokcan A, Yalını H. Türkiye'de kalp cerrahisinin tarihçesi. In: Duran E, editör. Kalp Dama Cer Derg. İstanbul: Çapa Tıp Kitabevi;2004.s.13-20.

3. Aytaç A. Dünyada ve Türkiye'de kalp cerrahisi. Turk Gogus Kalp Dama Cer Derg 1991;1:8-12.
4. Ali G. "Türkiye Yapay Kalpte Dünya Üçüncüsü" 01.11.2014 http://www3.istanbul.edu.tr/

5. Kervan Ü, Koç O, Özatik MA, et al. Distribution and service quality of the cardiovascular surgery clinics in Turkey. Turk Gogus Kalp Dama Cer Derg 2011;19:483-9.

6. Parsonnet $V$, Lean $D$, Bernstein $A D$. A method of uniform stratification of risk for evaluating the results of surgery in acquired adult heart disease. Circulation 1989;79:3-12.

7. Orhan G, Aka SA, Aydoğan H, et al. Kombine Koroner Arter Baypas Greft ve Kapak Ameliyatlarında Risk Faktörleri. Turk Gogus Kalp Dama Cer Derg 1998;6:427-30.

8. Toker ME, Mataracı I, Çalışkan A, et al. Open heart surgery and results in patient population aged 80 years and older Turk Gogus Kalp Dama Cer Derg 2009;17:151-6.

9. Fındık $O$, Aydın $U, A y Y$, et al. Open Heart Surgery in Kocaeli Derince Training and Research Hospital: Evaluation of the First Five Hundred Cases Koşuyolu Heart Journal 2015;18:348.

10. Crosby LH, Pifalo WB, Woll KR, et al. Risk factors for atriyal fibrillation after coronary artery bypass grafting. Am J Cardiol 1990;66:1520-2.

11. Sjögren J, Malmsjö M, Gustafsson R, et al. Poststernotomy mediastinitis: a review of conventional surgical treatments, vacuumassisted closure therapy and presentation of the Lund University Hospital mediastinitis algorithm. Eur J Cardiothorac Surg 2006;30:898-905. 